\section{A Carcinogenic Action of Testosterone, provoking Uterine Tumours in Mice}

The literature concerning the induction of tumours by hormones is very extensive ${ }^{1-4}$. CEstrogens especially appeared to play an important part in hormonal carcinogenesis ${ }^{5}$. Evidence of a carcinogenic action of androgens is very scant. Horning ${ }^{6}$ observed 3 theca-cell ovarian tumours in rats and 2 adrenal cortical tumours in hamsters after long-term treatment with testosterone. Also, Kirkman' suggested that testosterone propionate may act as a nonspecific carcinogen in the hamster.

In our experiments one pellet of 1-2 mgm. testosterone propionate was subcutaneously implanted into female mice of the $F^{\prime} 1$ hybrid $(C 57 B L \times d b a)$ twice a week. The treatment was started at the age of $1 \frac{1}{2}-3$ months and continued until the mice had to be killed because of their bad condition.

At post-mortem examination a surprisingly high percentage of uterine tumours was found (Table 1).

Table 1. UTERine Tumours Induced by Tustosterone

$\begin{array}{cccc}\text { No. of } & \begin{array}{c}\text { No. of } \\ \text { mice with } \\ \text { tumours }\end{array} & \begin{array}{c}\text { No. of } \\ \text { mice with } \\ \text { lung met. }\end{array} & \begin{array}{c}\text { Average } \\ \text { survival time } \\ \text { (months) }\end{array} \\ 14 & 6 & 3 & 18 \cdot 8 \\ 16 & 9 & 3 & 14 \cdot 7 \\ 12 & 11 & 4 & 15 \cdot 3\end{array}$

$\begin{array}{llrll}F_{1}(B D f) & 16 & 9 & 3 & 14 \cdot 7 \\ F_{1}\left(B D_{f}\right) & 12 & 11 & 4 & 15 \cdot 3\end{array}$

* Surviving the testosterone treatment for 10 months or more.

$\uparrow$ No difference was found in the survival time of the tumourbearing and the non-tumour-bearing mice.

In 26 of the 42 mice treated with testosterone uterine tumours were observed, and in 10 of the tumour-bearing mice metastases were present in the lings.

Most of these tumours were found either in the uterine cervix or in the unpaired uterine part. Only a few tumours were located in the horns of the uterus. The size of these tumours varied considerably. The largest diameter was about $25 \mathrm{~mm}$. and the smollest $4 \mathrm{~mm}$. The tumours were always strictly limited to the uterus and the vagina and no other tissue of the peritoneal cavity was involved. The surfaces of the cut tumours showed mostly a pink colour, but sometimes necrotic or hæmorrhagic areas were seen.

The histological pattern of the testosterone-induced uterine tumours was very characteristic and similar for the several tumours we have observed. In most of these tumours large trabeculx of cells were found next to more solid parts. The trabeculæ formed locally branched papillæ inside large sinuses. Most of the tumour cells had a diameter varying from 20 to $30 \mu$ and contained an abundant fine granular cytoplasm which stained mostly basophilic. The nuclei were large and relatively clear with prominent nucleolus (Fig. 1).

Most of the tumours showed an infiltrative growth in the muscular layers of the uterine wall. This fact together with the appearance of lung metastases are distinguishing marks of the malignancy of these tumours.

In most of the mice bearing a uterine tumour as well as in those without a gross uterine tumour one or more small pink nodules were observed in the uterus. Macroscopically and microscopically these nodules showed close similarities to the gross uterine tumours. We think we are justified in considering these nodules as stages preceding the malignant uterine tumours.

These nodules developed in the stroma of the endometrium. The epithelium and the muscular layers were not involved. The origin and the histo-

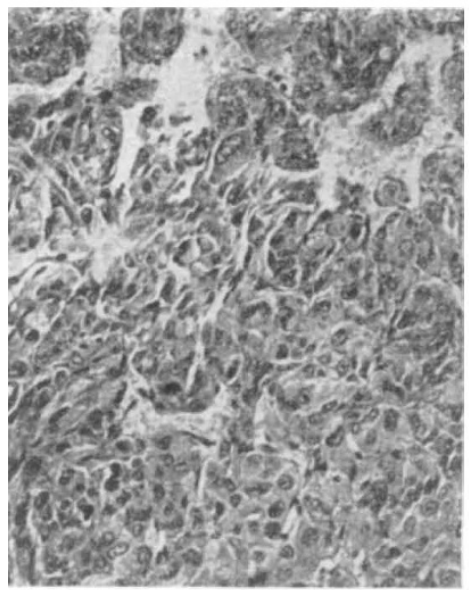

Fig. 1. Histological picture of a uterine tumour. ( $\times 200)$

logical aspects of the nodules are similar to the histological changes in the stroma of the endometrium during the first stages of pregnancy. On these similarities we base our hypothesis that the uterine tumours induced by testosterone are related to the decidua cells. The histological characteristics of these specific uterine tumours differ from the uterine carcinomas and uterine sarcomas so far described.
R. VAN NIE
E. L. Benedfitti
O. MÜHLBOCK

Laboratory Antoni van Leeuwenhoek-huis,

Netherlands Cancer Institute, Amsterdam.

${ }^{1}$ Gardner, W. U., Adv. Cancer Res., 1, 173 (1953).

'Kirschbaum, A., Cancer Res., 17, 432 (1957).

${ }^{3}$ Bielschowsky, F., and Horning, E. S., Brit. Med. Bull., 14, 106 (1958).

${ }^{4}$ Gardner, W. U., Pfeiffer, C. A., and Trentin, J. J., in The Physiopathology of Cancer, second ed., edited by Hamburger, $F^{\prime}$, and Fishman, W. H., 152 (Hoeber, New York, 1959). " Burrows, H., and Horning, E. S., Oestrogens and Neoplasia (Black-
well Scientific Publications, Oxford, 1952).

${ }^{\circ}$ Horning, E. S., Brit. J. Cancer, 12, 414 (1958).

Kirkman, H., Acta Un. Int. Cancer, 16, 143 (1960).

\section{Deiodination of Thyroxine-131 I in Tumour-bearing Rats}

Ir has been shown that hyperthyroidism induced by the administration of large doses of triiodothyronine increased the radiosensitivity of tumours in rats and in human beings ${ }^{1,2}$. Later it was found that hyperthyroidism induced in this way significantly enhances the growth of a solid non-metastatic myeloid leukæmia tumour of the Sprague-Dawley rat, a rat fibrosarcoma of a local strain and the Ehrlich mouse ascites tumour ${ }^{3}$.

In view of the profound effect of severe hyperthyroidism on tumour growth and its response to radiation, it became of interest to investigate the turnover of thyroxine in animals bearing these tumours.

The rate of deiodination of thyroxine was investigated by administration of a tracer quantity of labelled thyroxine and the amount of the inorganic iodide formed was determined by radioactive assay. To ensure complete retention of the iodide formed in the circulation, rats were surgically thyroidectomized $48 \mathrm{hr}$. before the turnover experiment. Tracer thyroxine, labelled with iodine-131 in the $3^{\prime}$ and $5^{\prime}$ 